\title{
Accelerate the Implementation Time of Kadiri University Clinic Constructions Projects Using Critical Path Method (CPM)
}

\author{
Faiz Muhammad Azhari, Agata Iwan Candra ${ }^{*}$, Dwifi Aprillia Karisma, Ashabul Yamin, and Fitry Rahmawaty \\ Faculty of Engineering, Kadiri University, 64115 Kediri, Indonesia
}

\begin{abstract}
The efficiency of project implementation time becomes one of the efforts in optimizing the use of implementation time. CPM is one of the network methods used to determine the critical path of each implementation. This research aims to optimize Time by applying CPM methods in the Kadiri University Clinic construction project in Kediri. The project consists of 2 floors with 12 essential items of work. The implementation time of the project is planned to be complete for 134 days. The data used in this study form a project schedule (Gantt chart). From the data, analysis of the sequence of implementation using the Work Breakdown Structure (WBS) method and carried out the calculation of earliest start (ES), latest start (LS), earliest finish (EF), and latest finish (LF). Critical paths are known from slack/float calculations and are depicted in the form of network diagrams. From the analyses, it is known that the project can be complete within 71 days. The results were 63 days earlier than planned. With the use of the CPM method in project scheduling, optimal timing and critical implementation are found. So that it can be used as a reference in the performance of the project implementation.
\end{abstract}

Keywords: Constructions, Critical Path Method, Management Project, Implementation Time.

\section{Introduction}

Project execution time is defined as the Time it takes to perform an implementation. Determining the timing of the performance of the project requires proper time management. With good time management, the implementation of the project will be by what is targeted. Project time management is a series of scheduling, monitoring, and controlling processes for the entire project implementation. Project scheduling is an actual implementation in construction projects such as building or other construction [1]. Project scheduling is arranged so that the project's performance is carried out in accordance with the target time set [1][2]. Advantages in doing good project scheduling management are the availability of implementation efficiency from various aspects such as Time, cost, material resources to tools and materials [3].

The success of a project can be reviewed based on the implementation process or timeliness of completion of the project implementation [4][5]. Improper scheduling of tasks will affect several things, such as delays, cost-bearing to implementation disputes [6][7]. The network method becomes one of the methods that can be applied in scheduling the implementation of the project. The critical path method (CPM) is one of the network methods used to determine the critical path of each performance. This method can be used to control and coordinate various implementations in work to complete the project in a timely manner [8]. CPM is the right choice in allocating resources at the minimum total cost, minimizing the total duration [9]. Time is used as the main criterion in determining critical pathways [10]. In the CPM method, network diagrams are designed to model the way a project will be built. If the network thoroughly models the project plan, the calculated predictions from the schedule will be reliable [11]. CPM is applied by calculating several operating parameters such as Earliest Start (ES), Latest Start (LS), Earlies Finish (EF), Latest Finish (LF), maximum available Time, and leisure time [12][13][14].

Some research on the application of the CPM method shows that the application of the method is able to find the optimal project implementation time. However, the construction project of the Kadiri University Clinic has not done optimal scheduling. The project is scheduled to be completed within 134 days. Planning the implementation of the project still uses a Gantt chart. Such methods cannot show a performance that is on a critical trajectory or execution that cannot be delayed [15]. So, if there is a delayed implementation will have an impact on the completion time of the project [16].

In this study, calculations were carried out regarding reducing the project implementation schedule using the CPM (Critical Path Method) method on the Kadiri

\footnotetext{
${ }^{*}$ Corresponding author : iwan_candra@unik-kediri.ac.id
} 
University Clinic. With the use of this CPM method, it is expected that the project schedule can get more efficient project implementation time and its implementation can be completed according to the planned Time.

\section{Research Method}

The research was conducted on the Kadiri University Clinic, which is located in Kediri city. The construction project consists of 2 floors, including preparatory work, soil and excavation, foundation, concrete, pairing and stucco, roof and ceiling, sanitary, electrical installation, floor coverings and walls, doors, and windows, painting, other work. The project is planned to be completed within 134 days with a budget plan of $1,3 \mathrm{M}$. The method used to carry out the project schedule's efficiency to get the optimal Time is the CPM (Critical Path Method) method [8].

\subsection{Research Data}

Research data in project implementation and schedule in the form of Gantt chart (figure 1) obtained directly from the source studied through the interview and observation process to the foreman and implementing contractor.

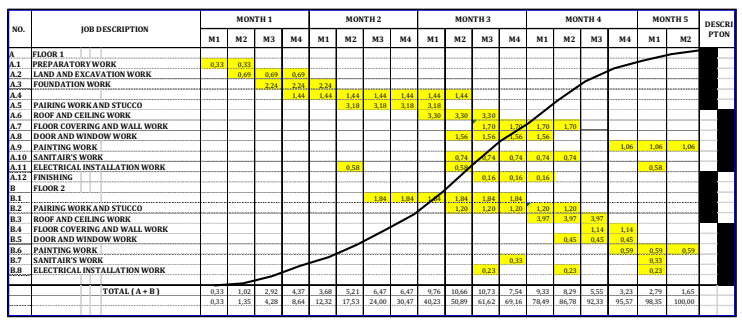

Fig. 1. Time Schedule

\subsection{Data Analysis Techniques}

Data analysis uses the CPM (Critical Path Method) method, with the following description:

\subsubsection{Identify execution order}

The execution sequence is identified with the Work Breakdown Structure (WBS), by determining the order of work that can be done simultaneously [17].

\subsubsection{Network of activities}

The series of activities is depicted in the form of a network diagram. A node limits each activity. The creation of a network of activities is carried out after it is known which implementation depends on each other.

\subsubsection{Critical Path}

Critical path determination uses the Activity on Arrow (AOA) approach consisting of a forward pass and backward pass to determine the schedule of each activity. ES (earlist start) and EF (earlist finish) are performed in the forward pass process. While in the backward pass process is done a calculation of LS (latest start) and LF (latest finish)[12][18].

\section{Result and Discussion}

\subsection{Execution Order}

In the order of implementation, the dependency is outlined between the implementation of one and the implementation of another. The execution order is used as a reference in the creation of a network of work. The order of performance on the Kadiri University Clinic construction project is outlined as follows:

Table 2. Description of implementation.

\begin{tabular}{|c|c|c|c|c|}
\hline Code & Description & Activity & Prodecessors & Duration \\
\hline A & $\begin{array}{c}\text { Preparatory } \\
\text { Work }\end{array}$ & A & - & 2 \\
\hline B & $\begin{array}{c}\text { Land and Quarry } \\
\text { Work }\end{array}$ & B & A & 6 \\
\hline C & $\begin{array}{c}\text { Foundation } \\
\text { Work }\end{array}$ & C & B & 14 \\
\hline D & Concrete Work & D & B,C & 20 \\
\hline E & $\begin{array}{c}\text { Pairing and } \\
\text { Stucco Work }\end{array}$ & E & D & 25 \\
\hline F & $\begin{array}{c}\text { Roof and Ceiling } \\
\text { Work }\end{array}$ & F & E & 20 \\
\hline G & Sanitair's Work & G & F & 7 \\
\hline H & $\begin{array}{c}\text { Electrical } \\
\text { Installation } \\
\text { Work }\end{array}$ & H & F & 5 \\
\hline I & $\begin{array}{c}\text { Floor Covering } \\
\text { And Wall Work }\end{array}$ & I & G,H & 14 \\
\hline J & $\begin{array}{c}\text { Door and } \\
\text { Window Work }\end{array}$ & J & E & 12 \\
\hline K & Painting Work & K & I & 7 \\
\hline L & Finishing Work & L & J, K & 2 \\
\hline
\end{tabular}

Table 1 above shows the order in which the execution, duration of Time, and implementation that precedes the next will form a network of work, as seen in figure 2

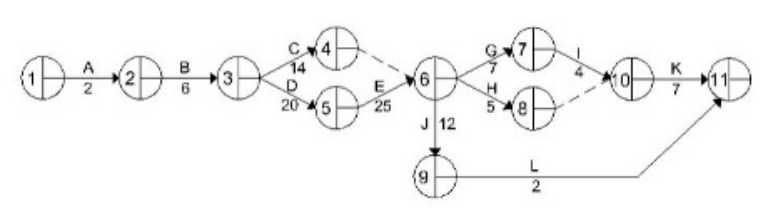

Fig. 2. Execution path

\subsection{Activity Schedule}

Determination of the activity schedule in the form of identification of the start time and the completion time of the implementation is done to determine the completion time. Identify that Time using the forward pass and backward pass process. ES (earlist start) and EF (earlist finish) are performed in the forward pass process. While during backward pass is done calculation LS (latest start) and LF (latest finish). The results of the calculation are described as follows: 
Table 2. Results of calculation of implementation activity schedule

\begin{tabular}{|c|c|c|c|c|c|c|}
\hline \multicolumn{2}{|c|}{ Implementation } & Century & \multicolumn{2}{|c|}{ Beginning } & \multicolumn{2}{c|}{ End } \\
\cline { 1 - 5 } $\mathrm{i}$ & $\mathrm{j}$ & Time & $\mathrm{ES}$ & $\mathrm{EF}$ & $\mathrm{LS}$ & $\mathrm{LF}$ \\
\hline 1 & 2 & 2 & 0 & 2 & 0 & 2 \\
\hline 2 & 3 & 6 & 2 & 8 & 2 & 8 \\
\hline 3 & 4 & 14 & 8 & 22 & 8 & 22 \\
\hline 3 & 5 & 20 & 8 & 28 & 8 & 28 \\
\hline 5 & 6 & 25 & 28 & 53 & 28 & 53 \\
\hline 6 & 7 & 7 & 53 & 60 & 53 & 60 \\
\hline 6 & 8 & 5 & 53 & 58 & 53 & 58 \\
\hline 6 & 9 & 12 & 53 & 65 & 57 & 69 \\
\hline 9 & 11 & 2 & 65 & 67 & 69 & 71 \\
\hline 7 & 10 & 4 & 60 & 64 & 60 & 64 \\
\hline 10 & 11 & 7 & 64 & 71 & 64 & 71 \\
\hline
\end{tabular}

The calculation of ES, EF, LS, and LF above shows that the Kadiri University Clinic construction can be completed within 71 days. The results were 63 days earlier than the planned Time using the Gantt chart.

\subsection{Critical Path}

Determination of critical implementation is based on the calculation of slack Time (slack Time). Slack Time is the free Time that every implementation has to be pushed back without causing any delay to the overall project. Critical implementation does not have a grace period (slack $=0$ ), meaning that the implementation must be started right on the ES so as not to result in increased project completion time.

Table 3. Critical activity analysis

\begin{tabular}{|c|c|c|c|c|c|c|c|c|}
\hline \multicolumn{2}{|c|}{$\begin{array}{c}\text { Implemen } \\
\text { tation }\end{array}$} & \multirow{2}{*}{$\begin{array}{c}\text { Century } \\
\text { Time }\end{array}$} & \multicolumn{2}{|c|}{ Beginning } & \multicolumn{2}{|c|}{ End } & \multirow{2}{*}{$\begin{array}{c}\text { Sla } \\
\text { ck }\end{array}$} & $\begin{array}{c}\text { Critical } \\
\text { Executi } \\
\text { on }\end{array}$ \\
\cline { 1 - 3 } $\mathrm{i}$ & $\mathrm{j}$ & $\mathrm{ES}$ & $\mathrm{EF}$ & $\mathrm{LS}$ & $\mathrm{LF}$ & & \\
\hline 1 & 2 & 2 & 0 & 2 & 0 & 2 & 0 & Ya \\
\hline 2 & 3 & 6 & 2 & 8 & 2 & 8 & 0 & Ya \\
\hline 3 & 4 & 14 & 8 & 22 & 8 & 22 & 0 & Ya \\
\hline 3 & 5 & 20 & 8 & 28 & 8 & 28 & 0 & Ya \\
\hline 5 & 6 & 25 & 28 & 53 & 28 & 53 & 0 & Ya \\
\hline 6 & 7 & 7 & 53 & 60 & 53 & 60 & 0 & Ya \\
\hline 6 & 8 & 5 & 53 & 58 & 53 & 58 & 0 & Ya \\
\hline 6 & 9 & 12 & 53 & 65 & 57 & 69 & 4 & - \\
\hline 9 & 11 & 2 & 65 & 67 & 69 & 71 & 4 & - \\
\hline 8 & 10 & 4 & 60 & 64 & 60 & 64 & 0 & Ya \\
\hline 10 & 11 & 7 & 64 & 71 & 64 & 71 & 0 & Ya \\
\hline
\end{tabular}

From the table above, it can be known that critical implementation occurs in preparatory work, soil and excavation, foundation, concrete, pair and stucco, roof and ceiling, sanitary, electrical installations, floor coverings, and walls, painting. With slack, Time occurs in the implementation of door and window work and other work. The critical path of described as follows:

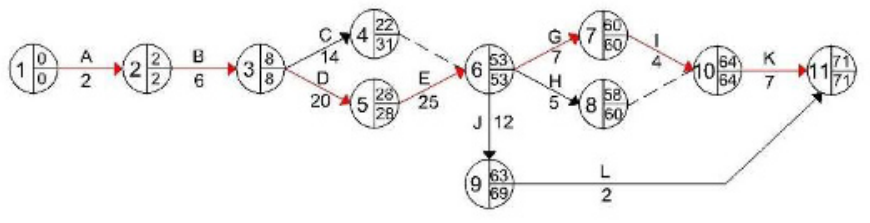

Fig. 3. Critical path

From figure 3 above, the critical path is implementing A, B, D, E, G, I, K.

\section{Conclusion}

The application of the CPM method can accelerate the implementation of project activities for 63 days from the planned Time using a Gantt chart. The critical path is on the implementation path $\mathrm{A}, \mathrm{B}, \mathrm{D}, \mathrm{E}, \mathrm{G}, \mathrm{I}, \mathrm{K}$ (preparatory work, soil and excavation, foundation, concrete, pairing and stucco, roof and ceiling, sanitary, electrical installation, floor and wall coverings, painting). By knowing the implementation and the critical path, the implementer can monitor the Time and not delay the implementation.

\section{References}

[1] N. Sembiring and A. Putra, "Scheduling evaluation in construction projects using the critical chain project management method," IOP Conf. Ser. Mater. Sci. Eng., vol. 830, no. 3, (2020), doi: 10.1088/1757-899X/830/3/032091.

[2] Y. Takakura, T. Yajima, Y. Kawajiri, and S. Hashizume, "Application of critical path method to stochastic processes with historical operation data," Chem. Eng. Res. Des., vol. 149, pp. 195-208, (2019), doi: 10.1016/j.cherd.2019.06.027.

[3] V. Maruvanchery, S. Zhe, and T. L. K. Robert, "Early construction cost and time risk assessment and evaluation of large-scale underground cavern construction projects in Singapore," Undergr. Sp., vol. 5, no. 1, pp. 5370, 2020, doi: 10.1016/j.undsp.2018.10.002.

[4] C. Kaliba, M. Muya, and K. Mumba, "Cost escalation and schedule delays in road construction projects in Zambia," Int. J. Proj. Manag., vol. 27, no. 5, pp. 522-531, (2009), doi: 10.1016/j.ijproman.2008.07.003.

[5] Chaterine and M. R. A. Simanjuntak, "Analysis of schedule project management's indicators and cost project management's indicators in interior construction," IOP Conf. Ser. Mater. Sci. Eng., vol. 1007, no. 1, (2020), doi: 10.1088/1757-899X/1007/1/012083.

[6] J. Bin Yang and C. K. Kao, "Critical path effect based delay analysis method for construction projects," Int. J. Proj. Manag., vol. 30, no. 3, pp. 385-397, (2012), doi: 10.1016/j.ijproman.2011.06.003.

[7] H. A. Baits, I. A. Puspita, and A. F. Bay, 
"Combination of program evaluation and review technique (PERT) and critical path method (CPM) for project schedule development," Int. J. Integr. Eng., vol. 12, no. 3, pp. 68-75, (2020), doi: 10.30880/ijie.2020.12.03.009.

[8] S. Atin and R. Lubis, "Implementation of Critical Path Method in Project Planning and Scheduling," IOP Conf. Ser. Mater. Sci. Eng., vol. 662, no. 2, (2019), doi: 10.1088/1757$899 X / 662 / 2 / 022031$.

[9] H. W. Wang, J. R. Lin, and J. P. Zhang, "Work package-based information modeling for resource-constrained scheduling of construction projects," Autom. Constr., vol. 109, no. January 2019, p. 102958, (2020), doi: 10.1016/j.autcon.2019.102958.

[10] A. H. Ganesh, A. H. Shobana, and R. Ramesh, "Identification of critical path for the analysis of bituminous road transport network using integrated FAHP - FTOPSIS method," Mater. Today Proc., vol. 37, no. Part 2, pp. 193-206, (2020), doi: 10.1016/j.matpr.2020.05.015.

[11] M. F. Nagata, W. A. Manginelli, J. S. Lowe, and T. J. Trauner, Delay Analysis Using Critical Path Method Schedules. 2018.

[12] S. Zareei, "Project scheduling for constructing biogas plant using critical path method," Renew. Sustain. Energy Rev., vol. 81, no. August 2017, pp. 756-759, (2018), doi: 10.1016/j.rser.2017.08.025.

[13] A. A. M. Boushaala, "An approach for project scheduling using PERT/CPM and Petri Nets (PNs) tools," Int. J. Mod. Eng. Res., vol. 3, no. 5, pp. 3200-3206, (2013).

[14] M. D. Sruthi and A. Aravindan, "Performance measurement of schedule and cost analysis by using earned value management for a residential building," Mater. Today Proc., vol. 33, no. xxxx, pp. 524-532, (2020), doi: 10.1016/j.matpr.2020.05.210.

[15] M. F. Nagata, W. A. Manginelli, J. S. Lowe, and T. J. Trauner, "Delay Analysis Using Bar Chart Schedules," Constr. Delays, pp. 109-132, 2018, doi: 10.1016/b978-0-12-811244-1.00006-9.

[16] C. N. Rolfsen and C. Merschbrock, "Acceptance of Construction Scheduling Visualizations: Bar-charts, Flowline-charts, or Perhaps BIM?," Procedia Eng., vol. 164, no. 1877, pp. 558-566, (2016), doi: 10.1016/j.proeng.2016.11.658.

[17] E. Siami-Irdemoosa, S. R. Dindarloo, and M. Sharifzadeh, "Work breakdown structure (WBS) development for underground construction," Autom. Constr., vol. 58, pp. 8594, (2015, )doi: 10.1016/j.autcon.2015.07.016.

[18] J. L. Richards, "Critical path method," Eng. Handbook, Second Ed., pp. 211-1-211-9, (2004), doi: 10.2307/3007695. 